\title{
PENGEMBANGAN PRODUK OLAHAN ROSELLA (Hibiscus sabdarifa Linn.) MENJADI MINUMAN JELLY DAN ROSELLA LEATHER
}

\section{(PROCESSING TECHNOLOGY OF ROSELLA (Hibiscus sabdarifa Linn.) : JELLY DRINK AND ROSELLA LEATHER)}

\author{
Mirna Isyanti dan Nami Lestari ${ }^{*}$ \\ *) Peneliti pada Balai Besar Industri Agro \\ Email : mirnaisyanti0305@gmail.com
}

Naskah diterima tanggal 29 Oktober 2012, disetujui tanggal 7 Mei 2013

\begin{abstract}
ABSTRAK
Penelitian pembuatan produk rosella dalam bentuk minuman jelly (jelly drink) dan rosella leather telah dilakukan di Balai Besar Industri Agro. Penelitian ini bertujuan untuk mengembangkan produk olahan berbahan rosella sebagai bentuk diversifikasi produk. Metode yang digunakan dalam penelitian ini adalah optimalisasi proses pengolahan minuman jelly dan rosella leather untuk mendapatkan formulasi yang disukai. Pembuatan minuman jelly rosella menggunakan rosella kering yang diekstrak dalam air dengan perbandingan 1:50 selama 15 menit. Konsentrasi jelly powder yang digunakan adalah sebesar $0,35 \%$ dan $0,40 \%$. Nilai gel strength produk minuman jelly rosella yang mendekati produk komersial dengan nilai 46,65 gf. Secara organoleptik, minuman jelly rosella yang paling disukai adalah penambahan jelly powder $0,4 \%$ dan gula $17,5 \%$. Hasil analisis kimia menunjukkan hasil kadar air minuman jelly rosella terpilih sebesar $72,2 \%$, kadar abu $0,30 \%$, jumlah gula $22,2 \%$, dan derajat keasaman $(\mathrm{pH}) 3,15$. Produk rosella leather berdasarkan organoleptik yang disukai berdasarkan parameter rasa, aroma, dan teksturnya adalah komposisi $75 \%$ rosella : $25 \%$ jambu biji, dengan nilai kadar air sebesar 16,8 \%, kadar abu 0,74\%, kadar gula 69,0\%, total asam $16,3 \mathrm{~mL}$ $\mathrm{NaOH} / 100 \mathrm{~g}$, dan jumlah serat pangan $4,08 \%$.
\end{abstract}

Kata kunci : Rosella, Minuman Jelly Rosella, Rosella Leather.

\section{ABSTRACT}

The study of development of rosella's product has been conducted in Centre for Agro-Based Industry. The study aimed to developed the diversification of rosella processing into a jelly drink and rosella leather product. The aim of this research is to develop the rosella processed in the form of jelly drink and rosella leather as a diversification product of rosella. The method using in the research is optimalization jelly drink and rosella leather process to get the best formulation based on panelist like most. This jelly drink consist of dry extract rosella in water for 15 minutes with formulation $1: 50$. Using organoleptic with hedonic testing, the rosella jelly drink that the panelist like most from the overall parameter is jelly powder $0,4 \%$ and sugar $17,5 \%$. Gel strength of rosella jelly drink that approaching commercial products is $46,65 \mathrm{gf}$. The chemical analysis of jelly drink rosella selected show that the water content is $72,2 \%$, the ash content is $0,30 \%$, the sugar content is $22,2 \%$, and the acidity are 3,15. Hedonic testing of rosella leather shows that the most likely product from the taste, flavor, and texture are product with composition $75 \%$ rosella and $25 \%$ pink guava. The chemical analysis of rosella leather selected shows that 
the water content is $16,8 \%$, the ash content is $0,74 \%$, the sugar content is $69,0 \%$, the total acid is $16,3 \mathrm{ml} \mathrm{N} \mathrm{NaOH} / 100 \mathrm{~g}$, the dietary fiber products is $4,08-5,42 \%$.

Keywords : Rosella, Jelly Drink Rosella, Rosella Leather.

\section{PENDAHULUAN}

$\mathrm{B}$ eberapa tahun terakhir ini minuman berbahan rosella mulai banyak dikenal sebagai minuman kesehatan (Sadikin, A. A, 2009). Rosella kini mulai dikembangkan petani untuk diambil kelopak bunga dan bijinya. Kelopak bungan tanaman ini selain mengandung asam malat yang rasanya segar dan berwarna menarik, juga kaya akan kandungan vitamin (A, B1, B2, C, D) dan asam amino (Devi, 2009).

Kelopak bunga rosella dapat diolah menjadi beberapa produk yang mempunyai nilai ekonomis cukup tinggi, yaitu berupa sirup atau minuman segar, selai dan manisan (Ditjenbun, 2008 di dalam Sadikin, A.A, 2009), teh herbal, dan jelly.

Salah satu inovasi penyajian produk yang merupakan perpaduan antara makanan dan minuman adalah dalam bentuk minuman jelly (jelly drink). Minuman jelly dibuat dari pektin, agar, karagenan, gelatin atau senyawa hidrokoloid lainnya dengan penambahan gula, asam dan atau bahan tambahan pangan lainnya. Sifat fisik penting jelly drink adalah kekentalan (viskositas), kelengketan, elastisitas, plastisitas, kelenturan, kekenyalan dan kekuatan gel (Setyaningsih dkk, 2010).

Produk yang berupa minuman jelly dapat menjadi alternatif minuman sari buah karena dapat mengatasi masalah pengendapan yang terjadi pada sari buah. Keunggulan produk minuman jelly yaitu dapat dikonsumsi sebagai minuman yang dapat menghilangkan dahaga sekaligus menahan lapar. Minuman jelly merupakan makanan ringan berbentuk gel, umumnya minuman jelly memiliki sifat elastis namun konsistensinya atau kekuatan gelnya lebih lemah bila dibandingkan dengan jelly sehingga mudah untuk disedot sebagai minuman (Ferizal, 2005).

Pemanfaatan rosella sebagai bahan dalam pembuatan jelly drink diharapkan dapat menghasilkan minuman yang disukai konsumen.

Pengembangan produk olahan rosella lainnya adalah berupa produk berbentuk lembaran tipis dengan ketebalan $2-3 \mathrm{~mm}$, kadar air $10-15 \%$, atau dapat disebut rosella leather.

Bahan baku fruit leathers dapat berasal dari berbagai jenis buah-buahan tropis ataupun subtropis dengan kandungan serat yang cukup tinggi seperti pisang, pepaya, mangga, nenas, jambu biji, apel, nangka, dan peach (Enie dan Nami, 1992; Reynold, 1993 di dalam Asben, 2007). Fruit leathers mempunyai konsistensi dan rasa khas sesuai dengan jenis buah yang digunakan.

Penelitian ini bertujuan untuk mengembangkan produk olahan berbahan baku rosella untuk skala kecil dan menengah dalam bentuk produk minuman jelly (jelly drink) dan rosella leather sebagai salah satu bentuk diversifikasi produk rosella.

\section{METODE PENELITIAN}

\section{Bahan dan Alat}

Bahan-bahan yang digunakan dalam pengolahan minuman jelly (jelly drink) rosella adalah kelopak bunga rosella (Hibiscus sabdariffa Linn) kering, gula pasir, jelly powder (kandungan berupa karagenan dan konjak), margarin, natrium metabisulfit, kalium sitrat, air, plastik cup, dan lid cup. Sedangkan bahan-bahan yang digunakan dalam pengolahan rosella leather adalah kelopak bunga rosella merah, jambu biji merah, gula pasir, glukosa bubuk, natrium metabisulfit, margarine, dan plastik Polipropilene (PP) ukuran $0.05 \mathrm{~mm}$.

Alat yang digunakan untuk mengolah minuman jelly rosella dan rosella leather adalah kompor, panci stainless, timbangan, neraca analitik, pengaduk, thermometer, 
kain saring, alat pengemas cup (cup sealer), blender, cabinet dryer, dan plastic sealer. Sedangkan untuk pengujian digunakan Texture Analyzer TAXTZi, pH meter, oven, dan perlengkapan untuk uji organoleptik.

\section{Metode}

Metode penelitian terdiri dari penelitian pendahuluan dan penelitian utama. Berdasarkan penelitian pendahuluan, formulasi terpilih untuk minuman jelly rosella adalah dengan perbandingan konsentrasi kelopak bunga rosella dan air sebesar (1:50). Pembuatan ekstrak rosella dilakukan dengan cara merebus kelopak bunga rosella kering dalam air mendidih yang bersuhu 95-100 C selama 15 menit. Rancangan percobaan yang digunakan adalah Rancangan Acak Kelompok dengan Percobaan Faktorial dengan $\mathrm{F}=\mathrm{A} \times \mathrm{B}=2 \times 2$, Faktor $(\mathrm{A})=$ konsentrasi jelly powder (\%) : $a_{1}=0,35 \%$, $a_{2}=0,40 \%$ dan Faktor $(B)=$ konsentrasi gula : $b_{1}=15 \%, b_{2}=17,5 \%$.

Pengujian untuk minuman jelly rosella meliputi : uji organoleptik (rasa, aroma, warna, tekstur, kadar air, kadar abu, kadar gula total, dan keasaman $(\mathrm{pH})$. Kekuatan gel (gel strength) terhadap produk minuman jelly rosella diukur dengan menggunakan alat Texture Analyzer. Sedangkan pengujian untuk rosella leather adalah uji organoleptik (uji hedonik), kadar air, kadar gula, kadar abu, serat pangan dan total asam. Proses Pembuatan Minuman Jelly dari Rosella dan Rosella Leather sebagai berikut :

Penelitian ini dibagi menjadi 2 bagian yaitu penelitian pendahuluan dan penelitian utama. Pada penelitian pendahuluan, dilakukan percobaan dengan trial dan error untuk penggunaan konsentrasi jelly powder yang berbeda, yaitu : $0,3 \% ; 0,35 \% ; 0,4 \%$; $0,45 \% ; 0,5 \% ; 0,55 \% ; 0,6 \% ; 0,65 \%$ dan $0,7 \%$.

Pada penelitian utama yang dilakukan adalah proses pembuatan minuman jelly rosella dengan tahapan proses sebagai berikut :

1. Ekstraksi kelopak bunga rosella ke dalam air mendidih $\left(95-100^{\circ} \mathrm{C}\right)$ selama 15 menit;

2. Penyaringan (dibuang ampasnya), sehingga diperoleh ekstrak kelopak bunga rosella;

3. Pencampuran dengan gula;

4. Pemanasan pada suhu $>90^{\circ} \mathrm{C}$ sambil diaduk sampai larut;

5. Penurunan suhu hingga $\pm 85^{\circ} \mathrm{C}$;

6. Pencampuran dengan jelly powder (sambil diaduk cepat), dimana konsentrasi yang digunakan berdasarkan hasil penelitian pendahuluan;

7. Penuangan pada cup plastic (hot filling) suhu $82-84^{\circ} \mathrm{C}$;

8. Penutupan kemasan (hot sealing);

9. Pasteurisasi (suhu $75^{\circ} \mathrm{C}$ selama 15 menit);

10. Diperolehnya minuman jelly rosella.

\section{HASIL DAN PEMBAHASAN}

\section{Minuman Jelly Rosella}

Pigmen antosianin yang banyak terdapat dalam kelopak bunga rosella menyebabkan teh rosella maupun hasil seduhannya berwarna merah. Kelopak bunga rosella mengandung $2 \%$ anthosianin berupa gossipetin (hydroxiflavone) dan hibiscin. Hibiscin merupakan pigmen utama yang terdapat dalam kelopak bunga rosella. Pigmen tersebut telah diidentifikasi dengan nama daphinphyline (Maryani dan Kristiana, 2008). Intensitas antosianin sangat dipengaruhi oleh nilai $\mathrm{pH}$. Pada $\mathrm{pH}$ rendah (asam), pigmen antosianin berwarna merah dan pada $\mathrm{pH}$ tinggi berubah menjadi violet kemudian menjadi biru. Konsentrasi pigmen juga sangat berperan dalam menentukan warna. Pada konsentrasi yang encer antosianin berwarna biru, sebaliknya pada konsentrasi pekat berwarna merah (Winarno, 1992).

Bahan pembentuk gel yang digunakan adalah jelly powder dengan kandungan karagenan dan konjak, 
bertujuan untuk memperoleh tekstur jelly yang lunak dan mudah disedot. Konjak dapat bereaksi secara sinergis dengan kappa karagenan dan xanthan gum untuk membentuk gel yang elastis. Konsentrasi jelly powder dapat mempengaruhi tekstur gel yang dihasilkan.

Pada penelitian pendahuluan dicoba penggunaan konsentrasi jelly powder sebesar $0,3 \%$; $0,35 \%$; $0,4 \% ; 0,45 \%$; $0,5 \%$; $0,55 \% ; 0,6 \% ; 0,65 \%$; dan $0,7 \%$. Akan tetapi minuman jelly yang dihasilkan dari konsentrasi $0,45 \%$ s.d. $0,7 \%$ tidak mudah untuk disedot. Oleh karena itu berdasarkan organoleptik terhadap daya sedot minuman jelly, digunakan konsentrasi sebesar $0,35 \%$ dan $0,4 \%$.

Uji hedonik atau uji kesukaan merupakan salah satu jenis uji penerimaan. Dalam uji ini panelis diminta untuk mengungkapkan tanggapan tentang kesukaan atau ketidaksukaan. Penilaian panelis berkisar antara 1 s.d 5, dimana $1=$ Sangat tidak suka; 2 = Tidak suka; $3=$ Netral; 4 = Suka; 5 = Sangat suka. Hasil analisis organoleptik minuman jelly rosella pada parameter rasa, aroma, daya sedot dan warna dapat dilihat pada Tabel 1.

Tabel 1. Hasil Uji Organoleptik Minuman Jelly Rosella

\begin{tabular}{l|ccccc}
\hline \multirow{2}{*}{$\begin{array}{c}\text { Perla } \\
\text { kuan }\end{array}$} & \multicolumn{5}{|c}{ Penilaian organoleptik } \\
\cline { 2 - 6 } & Rasa & Aroma & $\begin{array}{c}\text { Daya } \\
\text { sedot }\end{array}$ & Warna & $\begin{array}{c}\text { Total } \\
\text { Rata- } \\
\text { rata }\end{array}$ \\
$\mathrm{a}_{1} \mathrm{~b}_{1}$ & 3.33 & 2.87 & 3.53 & 3.93 & 3.41 \\
$\mathrm{a}_{1} \mathrm{~b}_{2}$ & 3.60 & 2.93 & 3.20 & 3.93 & 3.41 \\
$\mathrm{a}_{2} \mathrm{~b}_{1}$ & 3.47 & 2.87 & 3.27 & 3.60 & 3.30 \\
\hline $\mathrm{a}_{2} \mathrm{~b}_{2}$ & 3.33 & 2.80 & 4.70 & 3.73 & 3.64 \\
\hline
\end{tabular}

Keterangan :

$a_{1} b_{1}=$ Jelly powder $0.35 \%$, gula $15 \%$

$a_{1} b_{2}=$ Jelly powder $0.35 \%$, gula $17.5 \%$

$a_{2} b_{1}=$ Jelly powder $0.4 \%$, gula $15 \%$

$a_{2} b_{2}=$ Jelly powder $0.4 \%$, gula $17.5 \%$

Hasil uji organoleptik rasa minuman jelly rosella, berkisar antara $3.33-3.60$, dengan formulasi yang paling disukai adalah $a_{1} b_{2}$. Formulasi $a_{1} b_{2}$ ini menggunakan penambahan jelly powder sebesar $0,35 \%$ dan gula $17,5 \%$. Konsentrasi gula yang lebih tinggi, yaitu $17,5 \%$ lebih disukai dibandingkan 15\% karena rasa minuman jelly tidak terlalu asam. Untuk parameter aroma minuman jelly rosella, hasil uji berkisar antara 2.80 -
2.93, atau mendekati netral. Dari parameter daya sedot, hasil uji berkisar antara 3.20 - 4.70, nilai skor yang paling besar (paling mudah disedot) adalah formulasi $\mathrm{a}_{2} \mathrm{~b}_{2}$ yang terbuat dari penambahan jelly powder sebanyak $0,4 \%$. Daya sedot yang besar menunjukkan menunjukkan ketegaran yang besar. Selain itu pula disebabkan kandungan gula yang tinggi sebesar $17,5 \%$, dimana kemampuan gula untuk mengikat air akan membantu proses pembentukan gel sehingga akan menghasilkan gel yang lebih kompak, dan mempengaruhi karakteristik gel sehingga mudah untuk disedot.

Hasil uji organoleptik pada warna minuman jelly rosella, berkisar antara $3.60-$ 3.93. Formulasi $a_{1} b_{1}$ (skor 3,93 ) dan $a_{1} b_{2}$ (skor 3,93) merupakan produk minuman yang paling disukai warnanya.

Dari hasil analisis sidik ragam dengan menggunakan program SPSS Statistics 17 terhadap hasil uji organoleptik terhadap rasa, daya sedot, dan warna didapat bahwa tidak terdapat perbedaan yang signifikan antar sampel pada taraf nyata $1 \%$, sehingga tidak diperlukan uji lanjut.

\section{Analisa Mutu Produk}

\section{Kekuatan Gel}

Hasil analisis kekuatan gel minuman jelly rosella menggunakan Texture Analyzer disajikan pada Tabel 2.

Dari hasil uji (Tabel 2), terlihat bahwa formulasi $a_{2} b_{2}$, yaitu $0,4 \%$ jelly powder dan $17,5 \%$ gula mendekati produk yang ada di pasaran, dimana formula $a_{2} b_{2}$ dengan nilai gel strength sebesar 46,65 gf dan jarak $7,9255 \mathrm{~mm}$, sedangkan produk pasaran (X Drink) nilai gel strength sebesar $38,15 \mathrm{gf}$ dan jarak 7,9565 mm. Hal ini disebabkan kandungan gula yang lebih tinggi pada formula $a_{2} b_{2}$, sehingga nilai gel strength-nya lebih tinggi. Sedangkan untuk $a_{1} b_{1}$, terlihat nilai gel strength yang paling kecil sebesar 19,9 gf. Hal ini disebabkan oleh jumlah konsentrasi jelly powder yang digunakan lebih sedikit yaitu $0,35 \%$ dan kadar gula $15 \%$ sehingga daya ikat gula lebih lemah yang mengakibatkan gel strength menjadi lebih kecil. 
Tabel 2. Kekuatan Gel Minuman Jelly Rosella

\begin{tabular}{c|c|c|c}
\hline No & \multirow{2}{*}{ Kode } & \multicolumn{2}{|c}{ Rata-rata } \\
\cline { 3 - 4 } & & $\begin{array}{c}\text { Kekuatan } \\
\text { Gel }(\mathbf{g f})\end{array}$ & $\begin{array}{c}\text { Jarak } \\
(\mathbf{m m})\end{array}$ \\
\hline 1 & $\mathrm{a}_{1} \mathrm{~b}_{1}$ & 19.9 & 2.313 \\
2 & $\mathrm{a}_{1} \mathrm{~b}_{2}$ & 52.1 & 7.978 \\
3 & $\mathrm{a}_{2} \mathrm{~b}_{1}$ & 51.175 & 7.93375 \\
4 & $\mathrm{a}_{2} \mathrm{~b}_{2}$ & 46.65 & 7.9255 \\
5 & X Drink & 38.15 & 7.9565 \\
\hline
\end{tabular}

\section{Komposisi Kimia}

Hasil analisis fisiko-kimia minuman jelly rosella dapat dilihat pada Tabel 3 .

Tabel 3. Hasil Analisis Fisiko-Kimia Minuman Jelly Rosella

\begin{tabular}{|c|c|c|c|c|c|}
\hline \multirow[b]{2}{*}{$\begin{array}{l}\text { Parameter } \\
\text { Kadar Air } \\
\text { Kadar Abu } \\
\text { Jumlah gula } \\
\text { (dihitung } \\
\text { sebagai } \\
\text { sakarosa) } \\
\text { pH }\end{array}$} & \multirow[b]{2}{*}{$\begin{array}{c}\text { Satuan } \\
\qquad \begin{array}{c}\% \\
\% \\
\%\end{array}\end{array}$} & \multicolumn{4}{|c|}{ Kode Sampel } \\
\hline & & $\begin{array}{l}a_{1} b_{1} \\
80.6 \\
0.28 \\
15.1\end{array}$ & $\begin{array}{l}a_{1} b_{2} \\
76.2 \\
0.29 \\
19.2\end{array}$ & $\begin{array}{l}a_{2} b_{1} \\
81.3 \\
0.27 \\
14.9\end{array}$ & $\begin{array}{l}a_{2} b_{2} \\
72.2 \\
0.30 \\
22.2\end{array}$ \\
\hline \multicolumn{6}{|c|}{$\begin{array}{l}\text { Keterangan: } \\
a_{1} b_{1}=0,35 \% \text { jelly powder, gula } 15 \% \\
a_{1} b_{2}=0,35 \% \text { jelly powder, gula } 17,5 \% \\
a_{2} b_{1}=0,4 \% \text { jelly powder, gula } 15 \% \\
a_{2} b_{2}=0,4 \% \text { jelly powder, gula } 17,5 \%\end{array}$} \\
\hline
\end{tabular}

Hasil analisis fisiko-kimia minuman jelly rosella, menunjukkan kadar air minuman formula $a_{1} b_{1}$ sebesar $80,6 \%, a_{1} b_{2}$ sebesar $76,2 \%, a_{2} b_{1}$ sebesar $81,3 \%$ dan $\mathrm{a}_{2} \mathrm{~b}_{2}$ sebesar $72,2 \%$. Perbedaan kadar air disebabkan karena masing-masing formula mempunyai kandungan gula yang berbeda, dimana gula mempunyai kemampuan untuk mengikat air. Kadar air berpengaruh terhadap tekstur gel minuman jelly rosella. Kadar air pada formula $a_{2} b_{2}$ lebih rendah dibandingkan dengan formula lainnya karena mengandung gula lebih banyak $(17,5 \%$ sukrosa). Hal itu menyebabkan gel yang terbentuk menjadi lebih keras dibandingkan formula lainnya.

Untuk kadar abu formula $a_{1} b_{1}$ sebesar $0,28 \%, a_{1} b_{2}$ sebesar $0,29 \%, a_{2} b_{1}$ sebesar $0,27 \%$, dan $a_{2} b_{2}$ sebesar $0,30 \%$. Jumlah gula untuk formula $a_{1} b_{1}$ sebesar $15,1 \%$, $a_{1} b_{2}$ sebesar $19,2 \%, a_{2} b_{1}$ sebesar $14,9 \%$ dan $a_{2} b_{2}$ sebesar $22,2 \%$. Formula $a_{1} b_{2}$ dan $\mathrm{a}_{2} \mathrm{~b}_{2}$ mengandung jumlah gula yang lebih tinggi dibandingkan $a_{1} b_{1}$ dan $a_{2} b_{1}$, karena jumlah gula yang digunakan lebih besar yaitu $17,5 \%$.

Nilai $\mathrm{pH}$ minuman jelly termasuk asam, dimana untuk formulasi $a_{1} b_{1}$ sebesar $3,09, a_{1} b_{2}$ sebesar $3,17, a_{2} b_{1}$ sebesar 3,11 , dan $a_{2} b_{2}$ sebesar 3,15 . Nilai $p H$ dapat berpengaruh pada pembentukan gel, $\mathrm{pH}$ yang terlalu rendah akan menimbulkan sineresis (Winarno, 1992). Penyebab terjadinya sineresis pada minuman jelly adalah karena sifat karagenan yang memiliki kestabilan gel pada $\mathrm{pH} 7$, sedangkan pada $\mathrm{pH}$ dibawah 4.3 kekuatan gel dan viskositasnya akan menurun. Nilai $\mathrm{pH}$ yang rendah pada produk minuman jelly rosella menyebabkan produk tersebut memiliki rasa yang asam. Pada pembuatan minuman jelly, pemilihan jenis hidrokoloid dipertimbangkan berdasarkan sifat-sifat koloid terhadap sifat produk pangan yang dihasilkan, karena sifat pembentukan gel bervariasi dari satu jenis hidrokoloid ke hidrokoloid lainnya maka perlu dilakukan pengkombinasian dari jenis hidrokoloid tersebut. Penggunaan jelly powder yang memiliki kandungan karagenan dan konjak dilakukan karena pada umumnya karagenan dapat melakukan interaksi dengan makromolekul seperti protein sehingga mampu menghasilkan berbagai jenis pengaruh yaitu peningkatan viskositas dan pembentukan gel. Sedangkan konjak dipilih sebagai bahan yang ditambahkan pada karagenan dan dapat meningkatkan elastisitas dari gel yang terbentuk dan lebih stabil terhadap sineresis (Dwiyana, D.R, 2011).

\section{ROSELLA LEATHER}

Pengolahan rosella leather menggunakan kelopak bunga rosella yang berwarna merah dan penambahan buah jambu biji merah sebagai bahan pengisi dan juga sumber serat. Rosella leather adalah produk sejenis fruit leather yang berasal dari kelopak bunga rosella yang dihancurkan, dicampur dengan bahanbahan lain, yaitu : gula pasir, glukosa bubuk, natrium metabisulfit, margarin yang 
kemudian dikeringkan. Pengeringan bisa dilakukan dengan penjemuran atau bisa juga menggunakan pemanasan menggunakan alat pengering kabinet (oven kabinet) dengan suhu panas 50-60 C. Kandungan gizi rosella merah segar per 100 gram menurut Maryani dan Kristiana (2008) dapat dilihat pada Tabel 4.

Tabel 4. Kandungan Gizi

\begin{tabular}{c|cc}
\hline Parameter & $\begin{array}{c}\mathbf{1 0 0} \mathbf{g} \text { buah } \\
\text { segar }\end{array}$ & $\begin{array}{c}\mathbf{1 0 0} \mathbf{g} \\
\text { kelopak } \\
\text { segar }\end{array}$ \\
\hline Kalori & $49 \mathrm{kal}$ & $44 \mathrm{kal}$ \\
Kadar Air & $84,5 \%$ & $86,2 \%$ \\
Protein & $1,9 \mathrm{~g}$ & $1,6 \mathrm{~g}$ \\
Lemak & $0,1 \mathrm{~g}$ & $0,1 \mathrm{~g}$ \\
Karbohidrat & $12,3 \mathrm{~g}$ & $11,1 \mathrm{~g}$ \\
Serat & $2,3 \mathrm{~g}$ & $2,5 \mathrm{~g}$ \\
Kadar Abu & $1,2 \mathrm{~g}$ & $1,0 \mathrm{~g}$ \\
b-karoten & $300 \mathrm{ig}$ & $285 \mathrm{ig}$ \\
Ca (CaO) & $1,72 \mathrm{mg}$ & $160 \mathrm{mg}$ \\
Phospor (P) & $57 \mathrm{mg}$ & $60 \mathrm{mg}$ \\
Fe & $2,9 \mathrm{mg}$ & $3,8 \mathrm{mg}$ \\
Asam askorbat & $14 \mathrm{mg}$ & $14 \mathrm{mg}$ \\
\hline
\end{tabular}

Sumber : Maryani dan Kristiana (2008)

Hasil uji rosella leather dapat dilihat pada Tabel 5.

Tabel 5. Hasil Uji Rosella Leather

\begin{tabular}{|c|c|c|c|c|}
\hline Parameter & Satuan & A & B & C \\
\hline Kadar Air & $\%$ & 13,0 & 16,8 & 12,3 \\
\hline Kadar Abu & $\%$ & 0,77 & 0,74 & 0,73 \\
\hline $\begin{array}{c}\text { Kadar } \\
\text { Gula }\end{array}$ & $\begin{array}{c}\% \\
\text { (dihitung } \\
\text { sebagai } \\
\text { sakarosa) }\end{array}$ & 78,1 & 69,0 & 65,3 \\
\hline $\begin{array}{l}\text { Total } \\
\text { Asam }\end{array}$ & $\begin{array}{c}\mathrm{ml} \mathrm{N} \\
\mathrm{NaOH} / 100\end{array}$ & 17,3 & 16,3 & 7,94 \\
\hline $\begin{array}{c}\text { Serat } \\
\text { Pangan }\end{array}$ & $\begin{array}{l}g \\
\%\end{array}$ & 4,22 & 4,08 & 5,42 \\
\hline
\end{tabular}

Keterangan :

$A=100 \%$ rosella; $B=75 \%$ rosella : $25 \%$ jambu biji; $C$ $=50 \%$ rosella : $50 \%$ jambu biji merah,

Hasil analisis kadar abu rosella leather A, B dan C adalah 0,77\%, 0,74\% dan $0,73 \%$. Sebagian besar bahan makanan, yaitu sekitar $96 \%$ terdiri dari bahan organik dan air, sedangkan sisanya terdiri dari unsur-unsur mineral (Winarno, 1992). Mineral dalam bahan pangan biasanya ditentukan dengan pengabuan atau insinerasi (pembakaran). Abu merupakan residu anorganik yang didapat dengan memanaskan pada suhu tinggi, $>450^{\circ} \mathrm{C}$ (pengabuan) atau dengan pendestruksian komponen-komponen organik dengan asam kuat. Nilai Kadar abu menunjukkan kadar mineral yang dikandungnya. Semakin tinggi kadar abu, maka semakin tinggi pula kadar mineral yang dikandungnya.

Nilai Kadar air rosella leather A, B, C adalah $13,0 \% ; 16,8 \%$ dan $12,3 \%$. Perbedaan kadar air tersebut dikarenakan masing-masing produk mempunyai kandungan gula yang berbeda, dan gula mempunyai kemampuan untuk mengikat air. Pada pengolahan rosella leather, kandungan air diuapkan melalui pengeringan di dalam oven kabinet pada suhu $55-60^{\circ} \mathrm{C}$. Kadar air pada produk B masih tinggi sebesar $16,8 \%$, kemungkinan karena waktu pengeringan yang masih kurang lama.

Hasil pengujian total asam $(\mathrm{ml} \mathrm{N}$ $\mathrm{NaOH} / 100 \mathrm{~g}$ ) rosella leather $\mathrm{A}, \mathrm{B}$, dan $\mathrm{C}$ adalah 17,$3 ; 16,3$; dan 7,94 . Total asam produk $A$ dan $B$ lebih tinggi dibandingkan produk $\mathrm{B}$, karena kandungan rosella yang digunakan lebih banyak. Total asam menunjukkan banyaknya jumlah asam organik yang terkandung dalam suatu bahan pangan. Kelopak bunga rosella mengandung asam malat sebagai asam organik yang dominan sekitar 13\% (Maryani dan Kristiana, 2008), dengan demikian produk yang berasal dari rosella

Hasil analisis kadar gula rosella leather adalah 78,1\% (produk A), 69,0\% (produk B); dan 65,3\% (produk C). Pada pengolahan rosella leather ini digunakan pemanis alami yaitu gula pasir (sukrosa) dan glukosa bubuk. Peningkatan penggunaan gula pada pembuatan rosella leather berpengaruh terhadap kadar gula produk. Kadar gula produk meningkat dengan meningkatnya persentase gula yang diberikan. Peningkatannya sejalan dengan peningkatan gula yang diberikan. Penambahan gula bertujuan untuk meningkatkan citarasa makanan, memberikan penampakan tekstur yang baik 
pada makanan dan membantu memperpanjang umur simpan produk.

Serat pangan adalah senyawa berbentuk karbohidrat kompleks yang banyak terdapat pada dinding sel tanaman, tidak dapat dicerna dan tidak dapat diserap di dalam saluran pencernaan manusia, namun memiliki fungsi yang sangat penting bagi pemeliharaan kesehatan, pencegahan penyakit, dan komponen penting dalam terapi gizi (Astawan, M dan Andreas, L.K, 2008). Dalam penelitian ini digunakan jambu biji merah sebagai sumber serat pangan. Hasil pengujian menunjukkan jumlah kadar serat pangan produk $\mathrm{A}$ $(4,22 \%)$, B $(5,42 \%)$, dan C $(4,08 \%)$.

\section{Uji Organoleptik}

Hasil uji organoleptik rosella leather dapat dilihat pada Tabel 6 . Uji rasa rosella leather terlihat bahwa produk B paling disukai (dengan skor 4.0 atau suka), diikuti dengan produk $C$ ( 3,8 mendekati suka) dan produk A (2,67 tidak suka). Produk B merupakan formulasi campuran antara rosella $(75 \%)$ dengan jambu biji merah (25\%), produk C merupakan formulasi campuran rosella dengan jambu biji merah dalam perbandingan yang sama (50\%:50\%), sedangkan produk A merupakan formulasi murni rosella (100\%). Sehingga terlihat jelas bahwa penambahan buah jambu biji merah dapat memperbaiki tingkat kesukaan panelis terhadap rasa rosella leather, yang mempunyai rasa asam, sehingga memerlukan kombinasi dengan buah-buahan lain sebagai penambah rasa selain pemanis gula dan glukosa.

Dari hasil uji aroma rosella leather terlihat bahwa nilai skor produk B dan C adalah sama (yaitu 3,13 mendekati netral) diikuti dengan produk $\mathrm{A}$ (2,93 tidak suka, mendekati netral). Untuk produk A, karena bahan bakunya adalah rosella murni, maka memberi aroma asam.

Tekstur rosella leather yang paling disukai adalah produk $B(3,47)$ dan produk C $(3,33)$, diikuti oleh produk $A(2,73)$. Tekstur produk $A$ yang menggunakan $100 \%$ rosella terlihat lebih rapuh, karena tidak ditambahkan bahan pengisi, yaitu jambu biji.
Hasil analisis warna rosella leather, bahwa warna produk B (skor 4,2 suka) paling disukai, diikuti dengan produk $\mathrm{C}$ (skor 3,73 mendekati suka) dan A (skor 2,67 suka mendekati netral). Warna rosella leather yang dalam pengolahannya dicampur dengan jambu biji lebih disukai dibandingkan yang murni $100 \%$ rosella.

Tabel 6. Hasil Uji Rasa, Aroma, Tekstur, dan Warna Rosella Leather

\begin{tabular}{c|ccccc}
\hline \multirow{2}{*}{$\begin{array}{c}\text { Perla } \\
\text { kuan }\end{array}$} & \multicolumn{5}{|c}{ Penilaian organoleptik } \\
\cline { 2 - 6 } & Rasa & Aroma & $\begin{array}{c}\text { Tekst } \\
\text { ur }\end{array}$ & $\begin{array}{c}\text { Warn } \\
\text { a }\end{array}$ & $\begin{array}{c}\text { Total } \\
\text { Rata- } \\
\text { rata }\end{array}$ \\
A & 2.67 & 2.93 & 2.73 & 2.67 & 2.75 \\
B & 4.0 & 3.13 & 3.47 & 4.2 & 3.70 \\
\hline C & 3.8 & 3.13 & 3.33 & 3.73 & 3,49 \\
Keterangan : & & & \\
A = 100\% Rosella merah segar; $B=75 \%$ Rosella \\
merah segar: 25\% jambu biji merah; \\
C = 50\% Rosella merah segar: $50 \%$ jambu biji merah
\end{tabular}

\section{KESIMPULAN}

Minuman jelly rosella yang paling disukai dari seluruh parameter (rasa, aroma, tekstur, dan warna) adalah minuman dengan penambahan $0,4 \%$ jelly powder dan $17,5 \%$ gula, dan minuman yang paling mudah disedot adalah penambahan jelly powder $0,35 \%$ dan gula $15 \%$. Nilai gel strength minuman jelly rosella sebesar 46,65 gf, mendekati gel strength minuman jelly yang ada di pasaran. Rosella leather yang disukai adalah dengan komposisi $75 \%$ rosella dan $25 \%$ jambu biji merah.

\section{DAFTAR PUSTAKA}

Asben, A. 2007. Peningkatan Kadar lodium dan Serat Pangan dalam Pembuatan Fruit Leathers Nenas (Ananas comosus Merr) dengan Penambahan Rumput Laut. Laporan Penelitian Dosen Muda (Oktober 2007), Fakultas Pertanian, Universitas Andalas, Padang.

Devi, M. 2009. Dahsyatnya Khasiat Rosella. Cemerlang Publishing, Yogyakarta.

Dwiyana, D.R. Perbandingan Konsentrasi Hidrokolod dan Konsentrasi Asam Sitrat dalam Minuman Jeli Susu Sesuai Mutu dan Kualitas. Skripsi. 
Fakultas MIPA, Universitas Pakuan, Bogor.

Ferizal, S. 2005. Formulasi Jelly Drink dari Campuran Sari Buah dan Sari Sayuran. Skripsi. Fakultas Teknologi Pertanian, Institut Pertanian Bogor, Bogr.

Astawan, M dan Andreas Leomitro Kasih 2008. Khasiat Warna-warni Makanan. PT Gramedia Pustaka Utama, Jakarta.

Maryani, H dan L. Kristiana. 2008. Khasiat dan Manfaat Rosella (Revisi). PT. Agro Media Pustaka, Surabaya.
Sadikin, A.A. 2009. Pemanfaatan Rosella (Hibiscus safdariffa Linn) Dalam Pembuatan Minuman Jelly. Skripsi. Dep. Ilmu dan Teknologi Pangan, FATETA, IPB. Bogor.

Setyaningsih, D, Apriantono, A, dan Puspita Sari, M. 2010. Analisis Sensori untuk Industri Pangan dan Agro. IPB Press, Bogor.

Winarno, F.G. 1992. Kimia Pangan dan Gizi. PT. Gramedia Pustaka Utama, Jakarta. 